\title{
AMERICAN ONISCOID DIPLOPODA OF THE ORDER MEROCHETA.
}

\author{
By O. F. CоOK, \\ Custodian of Myriapoda.
}

In July, 1896, I collected near Auburn, Alabama, a small oniscoid diplopod the affinities of which have been difficult of determination. It is quite similar to a species described from Arkansas by Bollman as Sphariodesmus pudicus. The true genus Sphcriodesmus is, however, a very different form, and among described genera the type under discussion approximates rather to Cyclodesmus, but offers differences apparently important and at least unique.

Outside the Merocheta are to be found adaptations for securing safety by coiling up, conspicuously in the Oniscomorpha and in the family Striariidæ of the Colocheta, where the first segment is produced in front into a large hood for the protection of the head. In the Oniscomorpha the specialization for the habit referred to has reached its highest development, and the primitive condition of the ventral protected parts is evidence that this adaptation dates well back in the history of that order.

In the 20-segmented Merocheta the modifications necessary to render the habit of coiling up an effective means of defense have been executed in spite of greater initial difficulty, since the segments had, by the coalescence of all primitive sutures, become solid and intlexible chitinous rings. Moreover, this protective scheme seems to have been carried out, not once merely, but several times independently, for it appears from a comparative study of the five genera enumerated by Latzel as composing the subfamily Sphæriodesmia that these have nothing in common except this power of coiling closely. As conspicuous proof of the truth of this view, there need be noted only the fact that while some of the anterior segments are in each case enlarged to complete the armor of the closed animal, there have been at least three different inventions, if the expression may be permitted, to serve the same purpose. In Oniscodesmus and Cyrtodesmus the second segment is enlarged, in Cyclodesmus the third segment, and in Sphariodesmus the fourth and fifth, as may be better understood from reference to the plates. But even Oniscodesmus and Cyrtodesmus are widely distinct in all their characters, and the enlarged second segments do not resemble each other, showing that even where the same segment has been modified the histories of the changes may have been entirely independent. 
The new Alabama form resembles, as stated above, the genus Cyclodesmus rather than the others thus far mentioned. But from Cyclodes$m u s$, as well as from all other Merocheta, it differs conspicuously in the possession on each segment of a deep cavity located at the base of the carina in front. From the alcoholic material available $\mathrm{I}$ have not been able to demonstrate in connection with these pits the existence of any repugnatorial pores, and there are two facts that seem to negative such an explanation of their nature and function.

The first is that the cavities are not located in a position corresponding to that occupied by pores in any other member of the order. In general the pores of Merocheta are near the margin, but in the few instances where they are far removed from the lateral edge the pore is still distinctly a part of the carina, and not an excavation in the body cylinder as in the present case, to say nothing of the anomaly of finding a repugnatorial pore at the bottom of a deep cavity.

The second unique circumstance is that in no diplopoda are repugnatorial pores known to occur in front of the fifth segment, where they normally begin, all exceptions being in the suppression of the pores of that segment. The peculiar cavities of the new type are, however, apparent on the fourth and third segments! The only other paired cavities affecting the dorsal surface of the segments of diplopoda are the so-called "scobina" of the Anocheta, but these are found near the median line, are located near or at the anterior edge of the segment, and offer no similarity of form or structure which would give ground for asserting a homology with the pits discovered on the Alabama specimens under discussion.

It is also noteworthy that these cavities form a continuous series occurring on all segments from the third to the penultimate. Without exception the pore series is at least once interrupted in all known Merocheta, so that if the cavities were in form and function normal pores, they would still be unique in position, number, and distribution. It accordingly seems desirable to hold the newly recognized type as distinct from Cyclodesmus, notwithstanding the general resemblance in habit.

References to the descriptions and plates of other American onisciform genera are added, together with descriptions of an interesting new species of Oniscodesmus. A systematic arrangement is also proposed, and a key to the families is given, but this must be looked upon as artificial, the forms included not composing a natural group.

\section{ANALYTICAL KEY TO THE AMERICAN FAMILIES OF ONISCIFORM MEROCHETA.}

Segments with a posterior border composed of a transverse row of convex, rectangular areas; penultimate segment with its carinze as broad or broader than the small, rounded last segment: Family ONIscodesmid $\mathrm{E}$.

Segments without a posterior areate border; last segment subquadrate, much

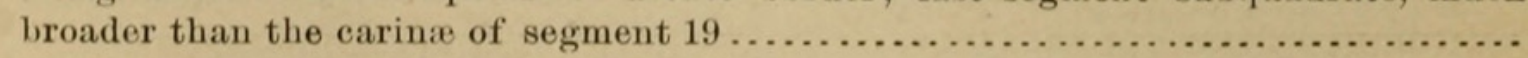


Second segment largest, the carinæ broad and expanded downward to protect the sides of the head; repugnatorial pores present; supplementary margin pectinate; last segment much broader than long, the posterior margin notched and tuberculate: Family CxrTODEsMide.

Second segment distinctly smaller than the third; repugnatorial pores wanting; supplementary margin entire or wanting; last segment nearly as long as broad, the

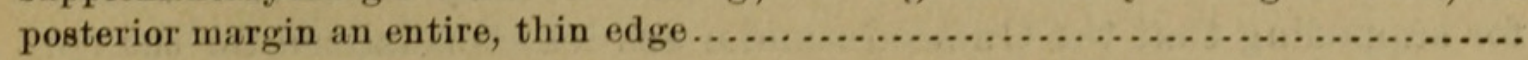

Carinæ increasing in size to segment 5 ; segments 4 and 5 with carinæ much larger than segment 3 ; antennae rather slender, joints 5 and 6 subequal: Family SPHERIODESMIDE.

Carinæ increasing in size only to segment 3 , which is much the largest; antennæ

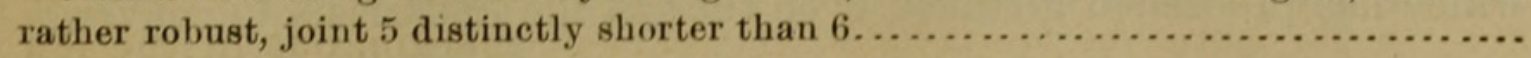

Surface of segments smooth, even, and polished, without pores or depressions of any sort: Family CyCLODEsmide.

Surface of segments granular-hispid; posterior subsegments convex or with a transverse row of conic tubercles; at the base of the carine in front a large, deep cavity: Family Desmonide.

\section{Family ONISCODESMID $\AA$ (Saussure).}

Oniscodesmides Saussure, Mem. Mex. Myriap., 1860, p. 14.

Oniscodesmide СоОк, Brandtia, 1896, p. 28.

Body very small, less than three times as long as broad; dorsum strongly convex, the carinæ very broad, sloping oblique'y downward; surface of segments smooth, the posterior margin ornamented by a transverse row of rectangular areas.

Antennæ robust, subclavate, joint 5 over twice as long as joint 6; joints 2 to 5 subequal in length.

Second segment with carinæ much the largest of all, broadly expanded and extending obliquely downward beyond the level of the others.

Lateral carinæ triangular, entire.

Repugnatorial pores distinct, located near the middle of the base of the carinæ.

Supplementary margin wanting.

Last segment small, the apex rounded and depressed, more or less concealed by the much larger penultimate segment.

Copulatory legs strongly divaricate, consisting of two rami, subequal in size and length.

The affinities of Oniscodesmus and its allies are evidently with the Pterodesmidæ and other forms generally arranged near Cryptodesmus. The transverse posterior row of rectangular areas are the most conspicuous evidence of this relationship, which is also indicated by the location of the pores, the short and robust antennæ, and the form of the terminal segments. This last feature separates the Oniscodesmidæ readily from all other American Merocheta adapted for being rolled into a sphere or close spiral.

In none of the known Oniscodesmida is the last segment larger than 
the carinæe of the preceding, while in the other four families, Cyrtodesmidæ, Sphæriodesmidæ, Cyclodesmidæ, Desmonidæ, the last segment is much broader than the carinæ, and forms a large rectangular plate closing the posterior face of the strongly arched armor.

This less perfect armor and less convex body may be taken as reasons for supposing that the Oniscodesmidx are less specialized for the coiling-up habit than the other families, but as this adaptation has evidently arisen independently in several eases which thus do not form a phylogenetic series, there is less satisfaction in attempting to decide which has proceeded furthest, even though the lines seem to converge.

ANALYTICAL KEY TO THE GENERA OF ONISCODESMIDE.

Pores borne on distinct, rounded tubercles: Genus Lignydesmus.

Pores not raised above the surface of the segments . . . . . . . . . . . . . . . . . . . . . . .

Second segment somewhat semicircular in lateral outline, without a posterior areate border; border of other segments short; sinus of segment 19 as broad as its carina: Genus Detodesmus.

Second segment merely oblong in lateral view, with an areate border which becomes longer on succeeding segments; sinus of segment 19 less than half as wide as its carinse: Genus Oniscodesmus.

\section{Genus ONISCODESMUS Gervais and Goudot.}

Oniscodesmus Gervais and Goudot, Ann. Soc. Ent. France, 1844, 2d ser., II, p. xxviii.

The authors of this genus described the first species as a Polydesmus, and at the end of the same paragraph erected the new genus for it.

The body is less convex and more similar in shape to the Pterodesmidæ than in the species described by Peters under Oniscodesmus, but which have been recognized as independent genera, as appears below.

The other distinguishing feature of the present genus is the small last segment, or rather the small part of the last segment, which can be seen from above through the small notch between the large carinæ of segment 19.

ONISCODESMUS ONISCINUS (Gervais and Goudot).

(Plate XXIX, figs. 1a, 1b.)

Polydesmus oniscinus Gervais and Govdot, Ann. Soe. Ent. France, 1844, 2d ser., II, p. xxviii.

Oniscodesmus oniscinus Gervais, Ann. Sei. Nat., 3d ser., I, p. 64, pl. v, figs. 7, 9; Apteres, 1847 , IV, p. 90, pl. xuIV, fig. 4.

Type.-A specimen supposed to be the type of this species is in the British Museum, and from this the two figures were traced.

Locality.-Colombia.

From a new species described below, O. oniscinus differs more conspicuously in the broader noteh of segment 19 , which in $O$. micrurus is closed to a narrow slit, as may be seen from a comparison of the figures. 
ONISCODESMUS MICRURUS, new species.

(Plate XXIX, figs. 2a-2k.)

Type.-No. 296, Berlin Museum.

Locality.-Bogota, Colombia.

Length, about $10 \mathrm{~mm}$; width, $4.1 \mathrm{~mm}$.

Color in alcohol, light horn brown.

Vertex rather flat, without hairs, sulcus rather shallow; clypeus sparsely hairy, densely rugulose transversely, antennæ rather densely pilose, especially distad.

First segment subreniform, about twice as broad as long, the anterior margin slightly concave, the posterior strongly convex; only the anterior corners are developed, and these are rounded; behind the anterior margin is a transverse row of about six slight, broadly rounded prominences.

Second segment with large, spatulate, broadly rounded carinæ, much exceeding in size, and extending far below those of the other segments. The lateral and anterior margins are raised, and behind the anterior margin is a prominent transverse ridge extending ebliquely mesad, but interrupted medianly by a distinct longitudinal impression.

Third and subsequent segments with narrowly triangular carinæ, becoming broader and more rounded caudad; surface of segments smooth, convex; parallel to the posterior margin is a transverse, somewhat irregular sulcus limiting a row of more or less rectangular convex areas present on all segments from the second to the eighteenth, but less distinct on those of the posterior end of the body.

Repugnatorial pores small, located near the middle of the carinæ, not far from their bases.

Supplementary margin wanting. The posterior edge of the dorsal part of the segment is produced beyond the actual rim of the body cylinder, so that the supplementary margin, if present, would not be visible from above. Another unusual adaptation is seen in the fact that this rim is deeply and broadly emarginate opposite the insertion of the legs, allowing the segments to be fitted against each other more compactly than when the cylindrical form of the individual segments remains complete.

Segment 19 with very broad semicircular carinæ, separated from each other only by a narrow slit, so that the last segment is from above almost entirely concealed, being considerably shorter than segment 19 .

Last segment greatly reduced, the apex, which projects beyond the anal valves, being merely a somewhat rounded tubercle bearing a few setæ.

Anal valves flat, scarcely margined; superior setiferous tubercles rudimentary, the setæ located near the superior corner of the valves; inferior setæ on slight tubercles above the middle of the valves. 
Preanal scale broadly triangular, setiferous tubercles distinct.

Sterna very narrow, the coxæ nearly in contact.

Legs sparsely hirsute, the third joint with a few long hairs on the ventral face, the succeeding joints with hairs shorter and more numerous.

The specimen which serves as the type of this species is preserved in alcohol and is marked as a type of Oniscodesmus rubriceps Peters, with which, as represented by the dried specimen supposed to be the true type, it has no close relationship, as a comparison of the drawings will show.

From Oniscodesmus oniscinus the present form differs most conspicuously in the structure of the last two segments.

\section{Genus LIGNYDESMUS Cook.}

Lignydesmus Соок, Brandtia, 1896, p. 28.

Second segment with anterior marginal ridge very prominent and broad, expanded below into a broad marginal rim.

Segments with posterior areate margin very convex and long, occupying over a third of the surface of the individual segments; surface of segments covered with a black adherent bloom or powder.

Repugnatorial pores located in contact with the transverse sulcus which bounds the areate margin, and elevated on a distinct rounded tubercle.

Segment 19 with subrectangular sinus exposing the broadly rounded last segment.

\section{LIGNYDESMUS RUBRICEPS (Peters).}

(Plate XXX, figs, $2 a-2 f$.)

Oniscodesmus rubriceps Peters, Monatsber, K. Akad. Wiss. Berlin, 1864, p. 617. Lignydesmus rubriceps Соок, Brandtia, 1896, p. 28.

Type.-Berlin Museum, a dried specimen.

Locality.-Bogota, Colombia.

\section{Genus DETODESMUS Cook.}

Detodesmus Соок, Brandtia, 1896, p. 28.

Second segment expanded in front on each side of the middle so that the lateral aspect is somewhat semicircular; anterior margin narrow and not so prominent as in Lignydesmus; areate margin wanting.

Segments with areate margin very short, occepying less than onefourth of the dorsal surface; areas small; surface of segments clean and polished.

Repugnatorial pores distinctly removed from the areate margin, not elevated on a tubercle.

Segment 19 with a rounded sinus about as wide as its carinæ; exposed part of last segment broadly rounded. 
Copulatory legs with a large, bulbous, hairy base bearing two rami of subequal length, of which the anterior is rather slender and ends in a point, while the posterior bears distally a subcapitate process turned laterad.

The apparent difference in detail, if not in type, between the copulatory legs of this genus and those of Oniscodesmus adds an argument, if any were necessary, to proof of the distinctness of the genera, although these important structures had not been described for Oniscodesmus when Detodesmus was recognized as separate.

\section{DETODESMUS AURANTIACUS (Peters).}

(Plate XXX, figs. 1a-1c.)

Oniscodesmus aurantiacus Peters, Monatsber. K. Akad. Wiss. Berlin, 1864, p. 530 Detodesmus aurantiacus Соoк, Brandtia, 1896, p. 26.

Type.-No. 245, Berlin Museum.

Locality.-Caracas, Venezuela.

\section{Family CYRTODESMIDA Cook.}

Cyrtodesmida Сook, Brandtia, 1896, p. 28.

Body small, five or six times as long as broad; dorsum very strongly convex, the carinæe broad, projecting almost directly downward; surface of segments pilose, hispid, or tuberculate, without an areate border

Second segment more or less enlarged and decurved, much exceeding all the others.

Lateral carinæ rounded or subquadrate, with a deep notch in the pos. terior margin at base.

Repugnatorial pores distinct, surrounded by a raised rim or borne on a special tubercle; the pores are located near the middle of the carinæ, near the base.

Supplementary margin finely and regularly pectinate.

Last segment much broader than long, subrectangular, the posterior margin notched and tuberculate; several setiferous tubercles are located below the margin.

It seems certain that the forms placed here can not be arranged under any other family. As yet the copulatory legs have not been described or figured, nor has there been the comparative study necessary to determine the affinties of the family. As a suggestion, however, the Doratodesmidie of the Malay region might be mentioned. Here, as in the Cyrtodesmidx, the body appears rather slender when extended, on account of the vertical carinæ, and when coiled it is more lenticular and less spherical than the other American families treated here. In the coiled animal there would be left on each side an open space were this not covered by the greatly enlarged carinæ of the second segment, against which the carinæe of most of the other segments can be brought into contact, thus forming a complete armor, 


\section{Genus CYRTODESMUS Gervais.}

Cyrtodesmus GervaIs, Apteres, 1847, IV, p. 92.

Second segment with carinæ broadly rounded, but not as much expanded and decurved as in the other genera associated in the present family.

Segmeuts evenly convex, densely velvety pilose.

Lateral carinæ with a deep notch in the posterior margin near the base.

Repugnatorial pores with the normal formula, located in the middle of the carinæ, slightly laterad from the notch, raised on distinct papillæ.

CYRTODESMUS VELUTINUS (Gervais and Goudot).

(Plate XXIX, figs. $3 a, 3 b$. )

Polydesmus velutinus Gervais and Goudot, Bull. Soc. Ent., France, 1844, 2d ser., II, p. xxviii.

Cyrtodesmus velutinus Gervais, Apteres, 1847, IV, p. 93, pl. xliv, fig. 5.

Type.-British Museum.

Locality.-Colombia.

\section{Genus ONCODESMUS Cook.}

Oncodesmus Соoк, Brandtia, 1896, p. 28.

The second segment is here much larger than in Cyrtodesmus, and the surface of the segments, instead of being densely and uniformly hispid, is beset merely with coarse granules, giving the animal an appearance very distinct from that of Cyrtodesmus. These differences are supplemented by others which in the absence of more detailed notes can not be stated till the types can be reexamined.

\section{ONCODESMUS GRANOSUS (Gervais and Goudot).}

Polydesmus granosus Gervais and Goudot, Ann. Soc. Ent., France, 1814, 2d ser., II, p. xxviii.

Cyrtodesmus granosus Gervais, Apteres, 1847, IV, p. 93.

Oncodesmus granosus СоoK, Brandtia, 1896, p. 28.

Type.-British Museum.

Locality._Colombia.

CYLIOCYRTUS, nev genus.

Type.-C. asper (Peters), from Colombia.

First segment small, included between the enormously enlarged flabellate carinæ of the second segment.

Segments densely covered with rough tubercles; carinæ notched at base.

Repugnatorial pores located on a special tubercle or papilla.

Supplementary margin regularly pectinate with long teeth. 
Last segment with the apical papillæ located below the projecting notched rim.

Anal valves and preanal scale entirely flat.

The affinities of this and the preceding genus may prove to lie with Doratodesmus rather than with other American forms or even Cyrtodesmus.

In the greatly enlarged second segment and the tuberculate segments this genus resembles Oncodesmus rather than Cyrtodesmus, but the hispidity of the tubercles gives a general appearance more like that of Cyrtodesmus, for Oncodesmus is coarsely granular and not hispid at all.

CYLIOCYRTUS ASPER (Peters).

(Plate XXX, figs. $3 a, 3 d$.)

Cyrtodesmus asper Peters, Monatsber, R. Akad., Wiss, Berlin, 1864, p. 618.

Type.-Berlin Museum.

Locality.-Bogota, Colombia.

Family CYCLODESMID A Silvestri.

Cyclodesmida Silvestri, Ann. Mus. Civ., Genova, 1895, XXXIV, p. 747.

Body very small, about five times as long as broad; dorsum very strongly convex, the carinæ broad, vertical; surface of segments smooth and polished.

Antennæ moderately robust, filiform, joint 6 slightly longer than joint 2 , and distinctly larger than joints 3 to 5 , which are subequal.

Second segment crescentic, much smaller than the third, which has the carinæ much expanded and projecting downward far beyond the level of the others.

Lateral carinæ rounded-triangular on anterior segments, with a straight lateral margin and distinct posterior corner on posterior seg. ments.

Repugnatorial pores wanting.

Supplementary margin wanting.

Last segment large, subquadrate, many times broader than the carinæ of segment 19; its posterior margin forms an even, thin edge.

Copulatory legs not known.

Genus CYCLODESMUS Humbert and Saussure.

Cyclodęmus Humbert and Saussure, Revue et Mag. Zool., 1869, p. 149.

CYCLODESMUS AZTECUS Humbert and Saussure.

Cyolodesmus aztecus Humbert and Saussure, Revue et Mag. Zool., 1869, p. 150; Etules sur les Myriap., 1872, p. 24, pl. I, figs. 3-3c.

Type.-Supposed to be in Paris.

Locality._Eastern cordillera of Mexico. 


\section{CYCLODESMUS PORCELLANUS Pocock.}

Cyclodesmus porcellanus Рососк, Journ. Linn. Soc., 1893, XXIV, p. 509, pl. XXXIX, figs. 1, $1 a$.

Type.-British Museum.

Locality.-Jamaica.

\section{CYCLODESMUS HUBBARDII Cook.}

(Plate XXXI, figs. 2a-2g.)

Cyclodesmus hubbardii Соок, Brandtia, 1896, p. 28.

Type.-No. 682, U.S.N.M.

Locality.-Jamaica.

Length, about $10 \mathrm{~mm}$; width, $2 \mathrm{~mm}$.

Color in alcohol, whitish, apparently mottled with grayish, as the delicate and translucent exoskeleton allows the contents of the alimentary canal to show through. On drying the specimens do not become pure white, as in $C$. porcellanus, which has, notwithstanding its smaller size, an apparently much firmer exoskeleton.

Segments without a notch in the posterior margin at the base of the carinæ.

The habitat of the specimens is given as "a small damp cave, Mandeville, Jamaica," where they were collected by Mr. H. G. Hubbard, for whom the species is named. The subterranean life may have reacted upon this species to render its exoskeleton thinner, colorless, and transparent. Specimens were compared with the types of $C$.porcellanus, a smaller species, distinct in the notched segments.

\section{Family SPH ERIODESMID AE (Humbert and Saussure).}

Sphariodesmii Humbert and Saussure, Revne et Mag. Zool., 1869, p. 149.

Spheriodesmiens HumberT and SAussure, Etudes, 1872, p. 20.

Body rather small, less than three times as long as wide; dorsum strongly convex, the carinæ very broad, curved downward so as to form with the dorsum nearly a semicircle; surface of segments smooth and polished.

Antennæ rather slender, filiform, joints 2 to 6 subequal, the fourth being slightly shortest, and the third and fifth shorter than the second and sixth.

First segment lenticular in outline instead of subelliptic for rhomboidal as in the other families.

Second and third segments crescentic, the third larger than the second, but much exceeded by the greatly expanded fourth and fifth segments.

Lateral carinæ entire, triangular on anterior segments, quadrate on posterior. 
Repugnatorial pores wanting.

Supplementary margin rather long, of rather firm and even texture, and quite entire.

Last segment subsemicircular, broader than the carinæ of segment 19; broader and shorter than the last segment in Cyclodesmida and Desmonida; posterior margin arr even, thin edge.

Copulatory legs of typical genus, simple, falcate.

This family may be understood to consist for present purposes of the monotypic genus Sphariodesmus, the second supposed species of which is certainly generically distinct and probably does not belong in the present family, as is pointed out below.

In Sphariodesmus the body cavity is distinctly more flattened than in the other glomeroid families, and the carinæ are decurved so as to project far below the ventral plane of the body cavity. This feature reaches perhaps its highest development here, and is correlated, as in similar forms, with more slender legs than the otherwise robust body would lead us to expect. It will be understood that, as these animals coil up, their legs may not be too bulky, and as the carinæ project far downward, the legs must have considerable length so as not to be interfered with in crawling.

The anterior segments are so entirely different from those of other families that the supposition of the independent acquisition of this provision for coiling up seems to be the only possible explanation, for it is well-nigh unthinkable, or at least violently unreasonable, to suppose that adaptation for this means of defense having been acquired by the enlargement, say, of the third segment the modification should have gradually been transferred to the fourth, for during the process of change the efficiency of the arrangement would have been destroyed. The form of the copulatory legs, the proportions of the antennal joints, together with the form of the segments as referred to above, are in the lise of the view that Sphariodesmus at least has no tangible relationship with the other glomeroid types of Merocheta. If this be admitted, the similarity in form of the posterior segments of the body in this family, the Cyclodesmidx and Desmonidx, must be looked upon as an instance of strikingly close approximation. We have, however, only to bring into the comparison the several genera of Oniscida, which have taken on practically the same form, to realize that the possibilities of approximation are great enough to be taken into account far more widely than is customary among systematists.

\section{Genus SPH ERIODESMUS Peters.}

Glomeridesmus SA Ussure, Linnsa Entom., 1858, XIII, p. 328; not Glomeridesmus Gervais.

Sphariodesmus Peters, Monatsber. K. Prenss. Akad. Wiss. Berlin, 1864, p. 529. 


\section{SPHÆRIODESMUS MEXICANUS (Saussure).}

(Plate XXXI, figs. 1a-1k.)

Glomeridesmus mexicanus SAUssure, Linnea Entom., 1858, XIII, p. 328; Mem. Mex. Myriap., 1860, p. 18, pl. I, figs. 1-1e.

Sphariodesmus mexicanus Peters, Monatsber. K. Akad. Wiss. Berlin, 1864, p. 529.-SAussure and Humbert, Etudes, 1872, p. 21, pl. I, figs. 1, 11 .

Type.-Supposed to be in Paris.

Locality.-Cordova, Mexico.

Two specimens of Sphariodesmus have come into my hands for study through the kindness of Professor Kraepelin, director of the Hamburg Museum. They seem to correspond in every particular with the descriptions and plates cited above. They are from Vera Cruz, Mexico, while the type of S. mexicanus was from Cordova, only 70 miles away. Thus, while it is well nigh impossible in some families of Diplopoda to fix species by descriptions of external characters, an identification seems justified in the present instance.

The details of the structure of the copulatory legs can be better understood from the plates, tl ese not having been previously described or figured.

Humbert and Saussure give the measurements of the typical specimens as 32 by $16 \mathrm{~mm}$., and state that they have four individuals measuring 16 by $5 \mathrm{~mm}$. which they propose to consider provisionally as the young of the present species, although already provided with twenty segments. These are indubitably a distinct species, probably of another genus.

\section{CYLIONUS, new genus.}

Type.-Cylionus gracilis (Humbert and Saussure), from Mexico.

From the descriptions and plates of this species it appears that at least a generic separation from sphariodesmus is necessary. The copulatory legs of Sphariodesmus are here made known for the first time, and a comparison with the plates of $\mathrm{C}$. gracilis shows a complete difference in type of structure. The resemblance is, indeed, with Desmonus, rather than with Sphariodesmus, there being a large incurved spine, presumably containing the seminal duct. It appears, also, in addition to the much smaller size (11 by $2.5 \mathrm{~mm}$.), that the body is much more strongly convex, laterally compressed, and slender; the fourth segment is larger than the fifth; the carinæe of other.segments are narrower and sinuate posteriorly, and the last segment is longer and has a transverse depression or furrow somewhat above the posterior margin. Moreover, from one of the drawings it appears that joint 6 of the antennæ is distinctly longer than joint 5. All the e differences point in the direction of Desmonus, but the enlarged fourth and fifth segments, and the want of any notice of the remarkable dorsal pits of Desmonus seem to forbid, for the present, reference to that vicinity, and the genus is accordingly left near Sphariodesmus, where it may be the more readily found. 


\section{CYLIONUS GRACILIS (Humbert and Saussure).}

Sphariodesmus gracilis Humbert and Saussure, Rev, et Mag. Zool., 1869, p. 149; Etudes sur les Myriapodes, 1872, p. 22, pl. I, figs. 2, $2 l$.

Type.-Supposed to be in Paris.

Locality.-Eastern cordillera of Mexico.

\section{DESMONID $A$, new family.}

Body very small, about four times as long as broad; dorsum very strongly convex, the carinæ broad, sloping somewhat obliquely downward; surface of segments finely hispid, transversely convex, or provided with a transverse row of rounded elevations or conic tubercles.

Antennæ rather robust, subclavate, the sixth joint distinctly longer and thicker than the others, joints 2 to 5 being subequal in length.

Second segment crescentic, much smaller than the laterally expanded and decurved third segment, which much exceeds all the others in size. The fourth segment has, however, the carinæ larger and more produced than the fifth and following segments, which is not the case in the Oyclodesmidx.

Lateral carinæe entire, subtriangular, becoming quadrate caudad.

Repugnatorial pores, if present, situated in large, deep cavities at the anterior shoulder of the carinæ at base. These cavities are not known in any other diplopoda.

Supplementary margin very short, delicate, and hyaline.

Last segment semielliptic, somewhar longer than broad, several times broader than the carinæ of segment 19; the posterior margin forms an even, thin edge.

Copulatory legs lying almost in contact, consisting of a bifid, robust ramus, and a slender simple attenuate process bearing the seminal duct and lying, when at rest, in a groove aloug the mesial face of the larger branch.

DESMONUS, nev genus.

Type.-Desmonus earlei, new species, from Alabama.

The generic characters are included among those given for the family. Should it be found necessary to associate here the genus Cyphodesmus Peters, it may be distinguished by the much larger size, slighter development of the carinæ of the third segment, and larger tubercles of the transverse row

DESMONUS EARLEI, new species.

(Plate XXXII, figs. $1 a-1 n$.)

Type.-No. 681, U.S.N.M.

Locality.-Auburn, Alabama.

Length, $7 \mathrm{~mm}$; width, $1.7 \mathrm{~mm}$. 
Color uniform light horn brown to whitish, usually appearing dark on account of adherent particles of earth or humus.

Vertex evenly convex, smooth and shining, without hairs; sulcus distinct; clypeus sparsely hirsute; antennæ sparsely hirsute, the hairs of the distal joints shorter and more numerous than those of the proximal.

First segment trapezoidal, anterior margin transverse, medianly slightly and very broadly emarginate, lateral corners somewhat rounded; lateral margins slightly curved, converging, posterior margin transverse, somewhat over half as broad as the anterior; the segment is over twice as broad as long; with the exception of a fine marginal raised rim its surface is smooth and even.

Second segment subcrescentic, the carinæ rather straight, and narrowly and acutely triangular; anterior and posterior margins of middle part of segment transverse; the carinæ project downward and forward so as to slightly exceed the anterior margin of the first segment, which is thus entirely included between them; margins of carinæ with fine raised rims. Surface of segment smooth and even.

Third segment saddle-shaped, much larger than any of the others. The carinæ are conspicuously broader than those of the other segments, and slightly broader than the dorsal part of the segment itself. They are rather strongly falcate, being somewhat prominent and arcuate in front and broadly emarginate behind. 'The posterior corner is somewhat produced. The carinæ also extend vertically much below a line drawn across the points of those of the second and fourth segments. Margins of carinæ with a distinct raised rim. Surface of segment smooth and even.

Fourth segment with carinæ conspicuously smaller than those of the third, aud triangular, like those of the following segments. They are, however, broader and produced somewhat farther ventrad than those of the fifth segment. The surface is distinctly more convex on its posterior part than with the preceding, and has traces of the prominences conspicuous on the other segments.

Segments dorsally finely and rather sparsely granular hispid, so that the animals are usually more or less covered with a layer of adherent particles of earth or rotten vegetable matter, which serves in life to render them very inconspicuous. Segments from the fourth to the penultimate have a transverse crest, usually of twelve rounded, broadly subconic prominences arranged in a row, except that the one on each side of the middle pair is somewhat smaller than those between which it stands and is slightly in front of them. With this exception the dorsal prominences are larger than those farther down; on posterior segments they become more sharply acute.

Carinæ of anterior segments from the fifth to the tenth rather narrowly triangular, their sides converging to a rounded point; from the middle of the body the carinæe are increasingly broader and more dis- 
tinctly truncate laterad; in all cases there is a distinct raised margin, which is slightly broader laterad; the anterior margin is straight, while the posterior is concave toward the end and convex near the base, there being a very slight notch or emargination where the carina joins the segment.

Repugnatorial pores not evident, unless located in the very large and deep cavities found close to the anterior base of the carinæ. These cavities are distinct on all segments from the third to the penultimate, those of the third segment being smaller than the others.

Supplementary margin very short, entire; the segments are very slightly constrieted at the transverse suture, and the anterior subsegment is very short and not sculptured.

Last segment nearly as high as broad, with traces of rounded prominences, the surface otherwise smooth; margin thin, even, slightly produced mesad; on the under surface, slightly removed from the margin, are two pairs of fine setæ equally distant from each other.

Anal valves flat, smooth, not margined, much exceeded by the edge of the last segment; preanal scale rounded, triangular, the setæ rising from punctations not located on tubercles.

Copulatory legs consisting of two unequal branches, a slender spinelike structure, simple and gradually narrowed to a sharp point, and a subclavate, much larger, distally bifid arm, which is hirsute on its lateral surface for about three-quarters of its length; on its inner surface it has a large longitudinal groeve, into which the slender arm may be laid.

This species is named for my friend Prof. F. S. Earle, who kindly assisted me in collecting a suite of specimens near Auburn, Alabama, in July, 1896. The most favored localities seemed to be woods consisting of deciduous trees with a mixture of pine, the same situations affected by the curious glomeroid form previously described as Onomeris underwoodii. On account of the roughened dorsum and adherent particles of dirt, Desmonus is even more inconspicuous than the smooth and polished Onomeris. Occurring with these were occasional specimens of the terrestrial isopod crustacean Armadillidium, and these three independent approximations to the same form, habits, and place in the economy of nature was very striking, and furnished instructive evidence on the possibilities of parallel development. The case is also worthy of note as furnishing an instance of close approximation in form, coloration, and habits, without evident reason for supposing that any implication of mimicry is involved.

\section{DESMONUS PUDICUS (Bollman).}

\section{(Platè XXX́ II, figs. $2 a, 2 b$.}

Sphariodesmus pudicus Bollmax, Entomologica Americana, 1888, IV, p. 3; Bull. U. S. Nat. Mus., 1893, No.46, p. 75.

Type.-No. 173 , U.S.N.M.

Locality.-Arkansas.

Proc. N. M. vol. xxi-30 
Closely allied to the preceding, but distinct in the much less prominent elevations of the segments. The surface itself seems, however, to be rougher than in D. earlei and the adherent matter is more abundant, giving the creature a more uniform and darker color. Following is Bollman's original description of the species, evidently drawn partly from living material. The U.S. National Museum contains one of the original specimens, the female.

General color pinkish, especially posteriorly, anterior half of segíents darkest, a black median dorsal line, antennæ dark, legs pale. Body widest and highest anteriorly, tapering posteriorly, smooth, setæe absent. Vertex smooth, somewhat sulcate. Antennæ subclavate, about equaling width of body. Dorsal plates smooth, four preceding the last with an indistinct row of obtuse scales; lateral plates, except the first, antepenult and penult, with their posterior margin serrate. Anal plate triangular with the angles rounded, sparsely pilose. Legs long and slender, extending beyond sides of body. Male: Ventral plate of second pair of legs produced into two short cones; coxæ of second and third pairs more pilose than others; copulation foot much twisted, end expanded and divided, pilose. Length of body, $7 \mathrm{~mm}$. ; width, $2 \mathrm{~mm}$.

Habitat.-Little Rock and Okolona.

From this it appears that the copulatory legs are also considerably different from those of $D$. earlei as here figured.

The curious cavities described on the segments of $D$. earlei are present in identical form in the present species, but their unique character and position might well account for their being overlooked. Moreover, they are in most cases filled up and concealed by adherent particles of dirt.

\section{Genus CYPHODESMUS Peters.}

Oniscodesmus SAUssure, Mem. Mex. Myriap., 1860, p. 20 (not Oniscodesmus Gervais and Goudot).

Cyphodesmuts Peters, Monatsber. K. Akad. Wiss. Berlin, 1864, p. 530.

The affinities of Cyphodesmus seem to lie with Desmonus; at least this is the inference one is obliged to draw from the descriptions and figures of the type and only known species. Generic distinctness is, however, indicated by the comparatively slight development of the carinæ of the third segment in Cyphodesmus, the much larger, more prominent, and somewhat spiniform process with which the segments are armed, and finally the much greater size, being several times as large as Desmonus. It would seem doubtful whether Cyphodesmus is able to coil up as effectively as Desmonus, as the anterior segments are figured like the others, with a transverse row of tubercles. No mention of the large cavities of the segments of Desmonus is made, but their unusual position might well account for their being overlooked, as in the case of Bollman's species of Desmonus. 


\section{CYPHODESMUS MEXICANUS (Saussure).}

Oniscodesmus mexicanus Saussure, Linnæa Entom., 1858, XIII, p. 328; Mem. Myr. Mex., p. 23, pl. I, figs 2-2d.

Cyphodesmus mexicanus Peters, Monatsber. K. Akad. Wiss. Berlin, 1864, p. 530.

Type.-Supposed to be in Paris.

Locality._Cordova, Mexico.

\section{EXPLANATION OF PLATES.}

\section{Plate XXIX.}

\section{Oniscodesmus oniscinus.}

Fig. 1a. First five segments, lateral view.

1b. Last segments, posterior view.

Oniscodesmus micrurus.

2a. Body, lateral view.

2b. First six segments, lateral view.

2c. Head and first two segments, anterior view.

2d. Antenna.

2e. Leg from a middle segment.

$2 f$. Seventh segment of male, anterior view, showing below the copulatory and normal legs.

2g. Copulatory leg, anterior view.

$2 h$. Same, anterior-lateral view.

$2 i$. Same, posterior view.

$2 j$. Last segments, posterior-dorsal view.

$2 k$. Same, ventral view, showing preanal scale and anal valves.

\section{Cyrtodesmus velutinus.}

3a. First three segments, lateral view.

3b. Carinz of segments 5 and 6 , latero dorsal view.

\section{Plate XXX. \\ Dètodesmus aurantiacus.}

Fig. 1a. Copulatory legs, posterior view.

1b. Last segments, posterior-dorsal view.

1c. First six segments, lateral view.

\section{Lignydesmus rubriceps.}

2a. A body-segment and pair of legs, posterior view.

2b. Last segments, posterior-dorsal view.

2c. First and second segments, anterior-dorsal view.

2d. Same, with head and antenna, anterior view.

2e. First six segments, lateral view.

$2 f$. Seventh segment, dorsal view, showing the poriferous tubercles. 


\section{Cyliocyrtus asper.}

Fig. $3 a$. Last three segments, posterior view.

3b. Same, ventral view.

3c. Carina of segment 15, showing the repugnatorial pore.

3d. Head and first three segments, lateral view.

\section{Plate XXXI.}

Sphariodesmus mexicanus.

Fig. 1a. Head, antenna and first seven segments, lateral view.

1b. Normal leg.

1c. A segment, posterior view.

1d. Head and first four segments, anterior view.

1e. A segment from the middle of the body, lateral view.

1f. Antenna.

1g. Copulatory legs, posterior view.

1h. Same, lateral view.

1i. Same, anterior view.

1j. Last six segments, lateral view.

$1 k$. Last three segments, posterior view.

\section{Cyclodesmus hubbardii.}

2a. Head and first four segments, anterior view.

$2 b$. Head and nine anterior segments, lateral view.

2c. Antenua.

2d. A segment, lateral view.

2e. Last two segments, posterior view.

$2 f$. Last four segments, lateral view.

$2 g$. A segment, posterior view.

\section{Plate XXXII.}

\section{Desmonus earlei.}

Fig. 1a. The entire animal, coiled into a sphere, lateral view.

1b. Head and first eight segments of extended animal.

1c. Antenna.

1d. Posterior view of segment from middle of body.

1e. Lateral view of same, showing location of deep cavity.

1f. Head and first four segments, anterior-dorsal view.

$1 g$. Seventh segment, ventral view, showing the copulatory legs in situ.

1h. Copulatory legs, anterior view.

1i. Same, posterior view.

$1 j$. Same, mesial view.

1k. Same, lateral view.

1l. Normal leg.

$1 m$. Segments 16 to 20 , ventral view.

$1 n$. Segments 17 to 20 , posterior view.

Desmonus pudicus.

2a. Last four segments, lateral view.

$2 b$. Segment from middle of body, lateral view. 


\section{$2 \mathrm{BHL}$ Biodiversity Heritage Library}

Cook, O. F. 1898. "American oniscoid Diplopoda of the order Merocheta." Proceedings of the United States National Museum 21(1154), 451-468.

https://doi.org/10.5479/si.00963801.21-1154.451.

View This Item Online: https://www.biodiversitylibrary.org/item/53529

DOI: https://doi.org/10.5479/si.00963801.21-1154.451

Permalink: https://www.biodiversitylibrary.org/partpdf/52607.

\section{Holding Institution}

Smithsonian Libraries

\section{Sponsored by}

Smithsonian

\section{Copyright \& Reuse}

Copyright Status: Public domain. The BHL considers that this work is no longer under copyright protection.

This document was created from content at the Biodiversity Heritage Library, the world's largest open access digital library for biodiversity literature and archives. Visit BHL at https://www.biodiversitylibrary.org. 